43 Ngai SW, Fan S, Li S, Cheng L, Ding J, Jing X, et al. A randomized trial to compare $24 \mathrm{~h}$ versus $12 \mathrm{~h}$ double dose regimen of levonorgestrel for emergency contraception. Hum Reprod 2004; 20: 307-311.

44 Ho PC, Kwan MS. A prospective randomized comparison of levonorgestrel with the Yuzpe regimen in post-coital contraception. Hum Reprod 1993; 8: 389-392.

45 Task Force on Postovulatory Methods of Fertility Regulation. Randomised controlled trial of levonorgestrel versus the Yuzpe regimen of combined oral contraceptives for emergency contraception. Lancet 1998; 352: 428-433.

46 Wu S, Wang $\mathrm{C}$, Wang $\mathrm{Y}$, Cheng W, Zuo S, Li H, et al. A randomized, double-blind, multicenter study on comparing levonorgestrel and mifepristone for emergency contraception. J Reprod Med 1999; 8(Suppl. 1): 43-46.

47 Hamoda H, Ashok PW, Stalder C, Flett GM, Kennedy E, Templeton A. A randomized trial of mifepristone $(10 \mathrm{mg})$ and levonorgestrel for emergency contraception. Obstet Gynecol 2004; 104: 1307-1313

48 Creinin MD, Schlaff W, Archer DF, Wan L, Frezieres R, Thomas $\mathrm{M}$, et al. Progesterone receptor modulator for emergency contraception: a randomized controlled trial. Obstet Gynecol 2006; 108: 1089-1097.

49 Espinos-Gomez JJ, Senosiain R, Mata A, Vanrell C, Bassas L, Calaf $\mathrm{J}$. What is the seminal exposition among women requiring emergency contraception? A prospective, observational comparative study. Eur J Obstet Gynecol Reprod Bio 2007; 131: 57-60.

50 Raymond E, Taylor D, Trussell J, Steiner MJ. Minimum effectiveness of the levonorgestrel regimen of emergency contraception. Contraception 2004; 69: 79-81.

51 Davis KR, Weller SC. The effectiveness of condoms in reducing heterosexual transmission of HIV. Fam Plann Perspect 1999; 31: 272-279.

52 Faculty of Family Planning and Reproductive Health Care (FFPRHC). Community Contraception Services Faculty Questionnaire. 2006. http://www.ffprhc.org.uk/pdfs/CommunityContraceptive.pdf [Accessed 4 May 2007].

53 National Institute for Health and Clinical Excellence. Longacting Reversible Contraception: The Effective and Appropriate Use of Long-acting Reversible Contraception (Clinical Guideline No. 30). London, UK: RCOG Press, 2005.

\title{
FACULTY MEMBERSHIP EXAMINATION
}

The Membership Examination (MFFP) consists of:

\section{Part 1 Multiple Choice Question Paper (MCQ)}

This 11/2-hour paper consists of 50 clinical science and applied science questions.

The examination will be held in London in April and October 2008 (dates to be confirmed). Applications for April 2008 must be received by 1 January 2008 and those for October 2008 must be received by 1 July 2008. The application form and information on the Part 1 can be obtained from the Faculty of Family Planning website (www.ffprhc.org.uk).

\section{$\square$ Dissertation or Case Reports}

Submission of one Dissertation (10 000 words) or two Case Reports (3000 words each).

Please visit the Faculty of Family Planning website (www.ffprhc.org.uk) for the latest changes to this part of the examination, and for information on exemptions.

\section{$\square$ Part 2 Examination (CRQ, MEQ, OSCE)}

This all day examination consists of:

Critical Reading Question examination paper (CRQ)

Modified Essay Question examination paper (MEQ)

Objective Structured Clinical Examination (OSCE)

Applications for the MFFP Part 2 held in June 2008 must be received by 3 January 2008. Please consult the revised Examination Regulations for changes to the entry requirements. Information on the Part 2 examination and the application form appear on the Faculty of Family Planning website (www.ffprhc.org.uk).

The qualification is subject to re-certification every 5 years.

For the revised MFFP Examination Regulations (December 2005), information and application forms please visit the Faculty of Family Planning website: www.ffprhc.org.uk (see Training \& Exams and MFFP Member). Also available on request from: Mrs Denise Pickford, Examinations, Faculty of Family Planning and Reproductive Health Care of the Royal College of Obstetricians and Gynaecologists, 27 Sussex Place, Regent's Park, London NW1 4RG, UK. Tel: +44 (0) 2077245629. Fax: +44 (0) 207723 5333. E-mail: denise@ffprhc.org.uk 